\title{
Metabarcoding of marine zooplankton in South Africa
}

\author{
SP Singh ${ }^{1 *}$ iD, JC Groeneveld ${ }^{1,2}$ iD, J Huggett $^{3,4}$ iD, D Naidoo ${ }^{2}$ iD, R Cedras $^{5}$ iD and S Willows-Munro² iD \\ 1 Oceanographic Research Institute (ORI), Durban, South Africa \\ 2 School of Life Sciences, University of KwaZulu-Natal, Pietermaritzburg, South Africa \\ ${ }^{3}$ Department of Forestry, Fisheries and the Environment (DFFE), Cape Town, South Africa \\ ${ }^{4}$ Department of Biological Sciences and Marine Research Institute, University of Cape Town, Cape Town, South Africa \\ ${ }^{5}$ Department of Biodiversity and Conservation Biology, University of the Western Cape, Cape Town, South Africa \\ * Corresponding author, e-mail: sohanasngh@gmail.com
}

\begin{abstract}
Metabarcoding is an emerging method in which DNA barcoding is combined with next-generation sequencing to determine the biodiversity of taxonomically complex samples. We assessed the current state of DNA barcode reference databases for marine zooplankton in South Africa and undertook a metabarcoding analysis to determine the species composition of samples collected with plankton tow nets. Analysis of DNA sequences mined from the literature and in online barcode reference databases revealed incomplete records for all taxa examined. Barcode records were dominated by meroplanktonic species with commercially important life-history phases (fishes and decapod crustaceans) and by species occurring in easily accessible nearshore habitats. Holoplanktonic species were underrepresented, despite making up the bulk of zooplankton biodiversity, including most potential indicator species. Metabarcoding analysis of plankton samples could identify $45 \%$ of amplicon sequence variants to species level based on BOLD databases (123 species) and similar numbers using GenBank and the MIDORI COI classifier. Morphological analysis of samples could not achieve comparable resolution at species level, but with some exceptions it recovered similar classes of organisms to those found by metabarcoding. The need for integrative molecular/morphological studies to increase and validate barcode reference databases of key zooplankton taxa is recognised. Metabarcoding of marine zooplankton in South Africa has now been successfully undertaken and the methodology is expected to facilitate high-resolution monitoring of zooplankton biodiversity in pelagic ecosystems and accelerate the discovery of new species.
\end{abstract}

Keywords: DNA barcoding, marine biodiversity, meroplankton, pelagic ecosystem, reference library, taxonomic assignment

Online supplementary material: A table detailing the DNA barcode records, mined from BOLD, for the phyla, classes and orders expected to be part of the marine zooplankton in South Africa and globally, is available at https://doi.org/10.2989/1814232X.2021.1919759.

Introduction

Zooplankton play an essential role as secondary producers in marine pelagic food webs, through biogeochemical cycling and energy transfer to higher trophic levels (Richardson 2008; Turner 2015), and as a pool of recruits for many crustacean, fish and mollusc species (Brierley 2017). Zooplankton communities typically exhibit rapid responses to environmental change, through changes in their abundance and distribution, and hence species composition (Richardson 2008), making them suitable as indicators of ecosystem health and biodiversity over both short and longer time-scales (Verheye et al. 1992, 1998, 2016; Verheye 2000; Huggett et al. 2009; Hutchings et al. 2012; Jarre et al. 2015).

Using morphological keys to identify zooplankton specimens is time-consuming because of their small size, large numbers, high diversity and community complexity (Leray and Knowlton 2015). Meroplanktonic larvae change rapidly throughout their growth from early to late larval development stages (Leis 2015), taxonomic keys are lacking for many species, and closely related species can exhibit cryptic morphology (Berry 1974; Matsuda et al.
2019). The morphological identification of zooplankton to species level requires extensive training to master the taxonomy of most zooplankton groups (Questel et al. 2021). Species-level resolution of samples will enable more-detailed biodiversity assessments and reveal 'hidden biodiversity' (Lindeque et al. 2013; Questel et al. 2021), enhance community-level analyses, and provide deeper insight into the life history and ecology of individual species (Ko et al. 2013).

DNA barcoding and online reference databases such as the Barcode of Life Data Systems (BOLD Systems, www. boldsystems.org) and GenBank (www.ncbi.nlm.nih.gov/ genbank) have revolutionised species identification and discovery over the past two decades (Hebert et al. 2003; Bucklin et al. 2011; Laakmann et al. 2020). Although multiple genes can be used for barcoding (Questel et al. 2021), a standardised $\sim 658$ base pair fragment of the COI gene is commonly used to distinguish between different species of most animal groups (Hebert et al. 2004; Ward et al. 2005; Hajibabaei et al. 2006). DNA barcodes can be 
used to distinguish between visually similar species, are independent of life stage, and reduce researcher bias by using a standard online reference system accessible to all researchers (Goetze 2010).

Metabarcoding is a special case of DNA barcoding applied to taxonomically complex samples that contain more than one organism or species (Dormontt et al. 2018). Metabarcoding uses the same reference databases as DNA barcoding, but allows for identification of multiple taxa simultaneously by using high-throughput sequencing methods (Taberlet et al. 2012; Cristescu 2014). The advance of next-generation sequencing (NGS) platforms (reviewed by Shokralla et al. 2012) allows for sequencing of large amounts of DNA fragments in a single run, with the prospect of rapidly determining the species composition of virtually any sample. Metabarcoding has successfully been applied to assess the biodiversity of zooplankton assemblages in several ocean regions and habitats (Casas et al. 2017; Djurhuus et al. 2018; Carroll et al. 2019; Hirai et al. 2020; Questel et al. 2021) but has not yet been applied in the SE Atlantic and SW Indian oceans.

Bucklin et al. (2011) estimated that there are more than 230000 species encompassing 31 marine metazoan phyla globally, and perhaps more than a million species yet to be discovered. Globally, the percentage of barcoded species has increased from $<10 \%$ in 2011 to approximately $23 \%$ in 2019 (www.barcodinglife.org). Of an estimated 12000 marine faunal species in South Africa, $13 \%$ have publicly available DNA barcodes (www.barcodinglife.org). Regionspecific DNA barcode reference databases have been shown to improve taxonomic resolution and the detection rates of species during metabarcoding (Govender et al. 2019; Questel et al. 2021), particularly where endemism is high, such as in South Africa where $~ 36 \%$ of marine species are endemic (Griffiths et al. 2010; Griffiths and Robinson 2016). Compilation of a region-specific reference database for southern African zooplankton is therefore advised; however, it has been hampered by the limited funding available for biodiversity surveys and too few trained taxonomists (Bezeng and van der Bank 2019).

We investigated the availability of DNA reference barcode sequences for marine zooplankton expected to occur in the coastal waters of South Africa as an initial step in developing a regional metabarcoding protocol. Priority faunal groups for assessment were: (i) taxa that commonly occur in samples collected from plankton nets towed between the surface and $10 \mathrm{~m}$ deep; (ii) crustacean, fish and mollusc taxa of value to fisheries in the region (mainly broadcast spawners with drifting larvae); and (iii) taxa with potential use as indicators of environmental change, including invasive species. Based on cross-referencing known species with those for which reference barcodes exist on accessible databases, we compared regional versus global barcode availability, with recommendations to develop reference databases to levels compatible with metabarcoding protocols. We undertook a metabarcoding analysis of plankton samples, collected with tow nets off the east coast of South Africa, to assess its potential as a high-resolution and accurate method to identify zooplankton species from mixed samples, and we compared the results with samples processed using traditional morphological identification.

\section{Materials and methods}

\section{Review of available barcode records}

Barcode records of marine taxa expected to occur in the zooplankton of coastal southern Africa were mined from BOLD, in January 2019, using the BOLD R-package (Chamberlain 2018). The 'bold_specimens' function in $\mathrm{R}$ was used to collate records for specified taxa by geolocation using the parameters 'taxon' and 'geo'. Lists of the global and southern African estimated known species per taxon were obtained from the South African Animal Checklist compiled by the South African National Biodiversity Institute (https://www.sanbi.org) and from Griffiths et al. (2010). Three categories of barcoding status were considered: (i) species for which no DNA barcode record could be found on any reference database; (ii) species with a barcode originating from samples collected in South Africa; and (iii) species with a barcode based on samples collected elsewhere. DNA barcoding records of specimens collected in regional waters are important, even when species are widely distributed or cosmopolitan, because geographic genetic variation can lead to intraspecific variability and possible misidentifications (Francis et al. 2010; Singh et al. 2017, 2018). Information on habitat, commercial importance, biogeography and depth range was obtained from FishBase (www. fishbase. org) to examine trends in barcoding frequency of different groups of fish species with meroplanktonic larvae.

\section{Metabarcoding of zooplankton samples}

For a comparison of zooplankton species composition obtained from metabarcoding with that obtained through identification using traditional microscopy and taxonomic keys, plankton nets with a $500-\mu \mathrm{m}$ mesh were towed at night in surface waters (1-5 m deep, 5 min per tow, speed 2-3 knots) over the continental shelf of KwaZulu-Natal Province on the east coast of South Africa. Zooplankton were preserved in $96 \%$ ethanol $(\mathrm{EtOH})$ and stored at $-20{ }^{\circ} \mathrm{C}$.

Thirteen samples were selected for traditional microscopic identification to determine species composition, relative abundance per taxon and frequencies of occurrence. Morphologically similar specimens were pooled, identified to the lowest possible taxonomic level, counted and photographed before storage in $8-\mathrm{ml}$ pill vials containing $96 \% \mathrm{EtOH}$. Photographs were taken using a ZEISS AxioCam ERc5s camera connected to a ZEISS dissecting microscope. Relative abundance and frequencies of occurrence at class level were determined across all samples analysed.

Twelve samples from the same area were selected for metabarcoding. To avoid contamination, DNA extractions were performed in an area separated from where PCR reactions were performed; surfaces were sterilised with $4 \%$ $\mathrm{NaOH}$ for $10 \mathrm{~min}$, followed by washing with distilled water and ethanol; and surfaces were exposed to ultraviolet light for $10 \mathrm{~min}$ before and after molecular work. A total of $6 \mathrm{ml}$ of zooplankton per sample was centrifuged at $3000 \mathrm{rpm}$ for $60 \mathrm{~s}$ and the supernatant removed, with $40 \mathrm{mg}$ of tissue from each sample used for DNA extraction using the Qiagen DNeasy Blood and Tissue kit (Qiagen). A blank DNA extraction was performed to assess levels of contamination. 
The DNA from each sample was pooled in equimolar concentrations to obtain an overview of taxa expected in the region. $\mathrm{PCR}$ reactions were performed in triplicate using the mICOlintF (Leray et al. 2013) and HCO2198 (Folmer et al. 1994) primers and a reaction volume of $25 \mu \mathrm{l}$ containing $0.02 \mathrm{U} \mathrm{\mu l}^{-1}$ of Q5 High-Fidelity DNA Polymerase (New England BioLabs, Inc.), 1X Q5 reaction buffer, 1X Q5 high GC enhancer, $200 \mu \mathrm{M}$ of dNTPs, $0.5 \mu \mathrm{M}$ each of the forward and reverse primers, and 5-10 ng of template DNA, then made up to $25 \mu \mathrm{l}$ with nuclease free water. Negative and positive controls were included in the PCR runs. The thermal-cycling profile consisted of initial denaturation at $98{ }^{\circ} \mathrm{C}$ for $30 \mathrm{~s}$, and 25 cycles of denaturation at $98^{\circ} \mathrm{C}$ for $10 \mathrm{~s}$, annealing at $46{ }^{\circ} \mathrm{C}$ for $30 \mathrm{~s}$, extension at $72{ }^{\circ} \mathrm{C}$ for $30 \mathrm{~s}$, and a final extension step at $72{ }^{\circ} \mathrm{C}$ for $4 \mathrm{~min}$. PCR products were cleaned using the Agencourt Ampure XP beads (Beckman Coulter Life Sciences Inc.) following the manufacturer's protocols. Library preparation using the Nextera Index Kit (V3, Illumina Inc.) and subsequent PCR-clean-up as well as NGS using the Illumina MiSeq paired-end 300-bp platform was performed by the KwaZuluNatal Research Innovation and Sequencing Platform (KRISP). To test the viability of the sampling unit (i.e. a plankton tow), the above process was repeated for DNA extracted from a single tow-net sample.

Pre-processing of sequencing reads was carried out using Qiime2 2019.4 (Bolyen et al. 2019) on the Centre for High Performance Computing cluster (www.chpc.ac.za). The dada2 algorithm (Callahan et al. 2016) implemented in Qiime2 was used to perform quality checks, chimera removal, filtering, trimming of primers, truncation of forward and reverse reads, and merging of the paired-end reads into amplified sequence variants (ASVs). A FASTA formatted file of the ASVs was used to query the BOLD database (www.barcodinglife.org) and GenBank using the BLAST algorithm (Basic Local Alignment Search Tool, https://blast.ncbi.nlm.nih.gov) to assign and cross-reference taxonomic identification. We also used the MIDORI COI classifier in Qiime2 to classify species (Leray et al. 2018). We used a threshold of $95 \%$ similarity to delimit species. Sequences that were not from zooplanktonic organisms and with ASV numbers of $<5$ were removed prior to evaluating species detection success rates.

\section{Results}

\section{Progress with zooplankton barcoding records}

Mining of zooplankton DNA records on BOLD revealed proportionally fewer representative barcode records per taxon from South Africa compared to those available globally (Figure 1; Supplementary Table S1). Ray-finned fish Actinopterygii were the most comprehensively sampled aquatic group globally (64\% of 33000 species from marine and freshwater species barcoded) and in South Africa (48\% of 2200 species barcoded). Overall, 20000 fish species comprising >280 000 specimens have DNA barcodes available on the global Fish Barcode of Life platform (FISH-BOL, http://www.fishbol.org). Steinke et al. (2016) generated DNA barcodes for 3125 adult fish specimens, comprising $43 \%$ of known species from southern Africa and including 189 new barcode records. Out of DNA barcodes of 2526 immature specimens (eggs, larvae and juveniles), $89 \%$ could be successfully assigned to 450 species, confirming the value of barcodes in identifying cryptic egg or larval stages to species level.

Of 41000 crustacean species known globally, 18\% had publicly available DNA barcode records. Proportionally, water fleas Cladocera (90\% of 658 species), krill Euphausidae (70\% of 90 species), copepods (70\% of 3220 species), amphipods (26\% of 7000 species) and decapods ( $24 \%$ of 18000 species) were well represented, but $<2 \%$ of 13000 ostracod species had barcodes. Barcode records were available for $6 \%$ of 1744 known crustacean species in South Africa. Excluding Leptostraca (50\% of 4 species), only Mysida (21\% of 58 species) and Decapoda (10\% of 750 species) were well represented. No South African barcode records could be found on BOLD for Cladocera, hooded shrimp Cumacea, Isopoda, mantis shrimp Stomatopoda, fish lice Arguloidea, seed shrimp Ostracoda or sea spiders Pycnogonida, although records may be available on other databases such as GenBank.

Molluscs comprise 85000 extant species (Rosenberg 2014), mainly in marine habitats. Of $\sim 60000$ gastropod species globally, $20 \%$ had representative barcodes, compared with $6 \%$ of $>2250$ species known from South Africa. Of an estimated 9200 bivalve species globally, $24 \%$ had barcodes, compared with $2 \%$ of 650 species known from South Africa. Of 850 cephalopod species globally, $69 \%$ had barcodes on BOLD, compared with $2 \%$ of 195 species from South Africa; $39 \%$ of 650 chitons Polyplacophora worldwide had barcodes, compared with $28 \%$ of 29 species in South Africa.

Cnidarians are a highly diverse group with some 11000 known species, including corals Anthozoa and jellyfish Cubozoa, Hydrozoa, Scyphozoa and Staurozoa (Branch et al. 2010). Of 7500 species of Anthozoa known globally, $21 \%$ had barcodes, compared with $1.7 \%$ of 174 species in South Africa. Globally, $13 \%$ of 3500 hydroids and hydra-like animals Hydrozoa, $63 \%$ of 175 true jellyfish Scyphozoa, and $31 \%$ of 36 box jellyfish Cubozoa had barcodes, compared with $10 \%$ of jellyfish and $0.8 \%$ of hydrozoans from South Africa.

Echinoderms (starfish Asteroidea; feather-stars Crinoidea; sea urchins Echinoidea; sea cucumbers Holothuroidea; and brittle stars Ophiuroidea) have pelagic larvae which are difficult to identify morphologically (Knolt et al. 2003). Approximately $32 \%$ of echinoderms had barcodes on BOLD, compared with $<1 \%$ of the 410 known species in South Africa.

The Porifera are ideal for DNA barcoding because they have few diagnostic characters for taxonomic identification and a slow evolutionary rate (Vargas et al. 2012). The Sponge Barcoding Project (www.spongebarcoding.org) generated DNA barcodes for $13 \%$ of some 6000 sponge species globally, compared with $3 \%$ of 346 known species from South Africa.

\section{Effects of habitat, depth, distance from shore, and commercial importance on barcoding success}

Barcoding has been most successfully applied to reef-associated fish species $(49.6 \%$ of all South African marine fish barcodes), followed by nearshore demersal fish 


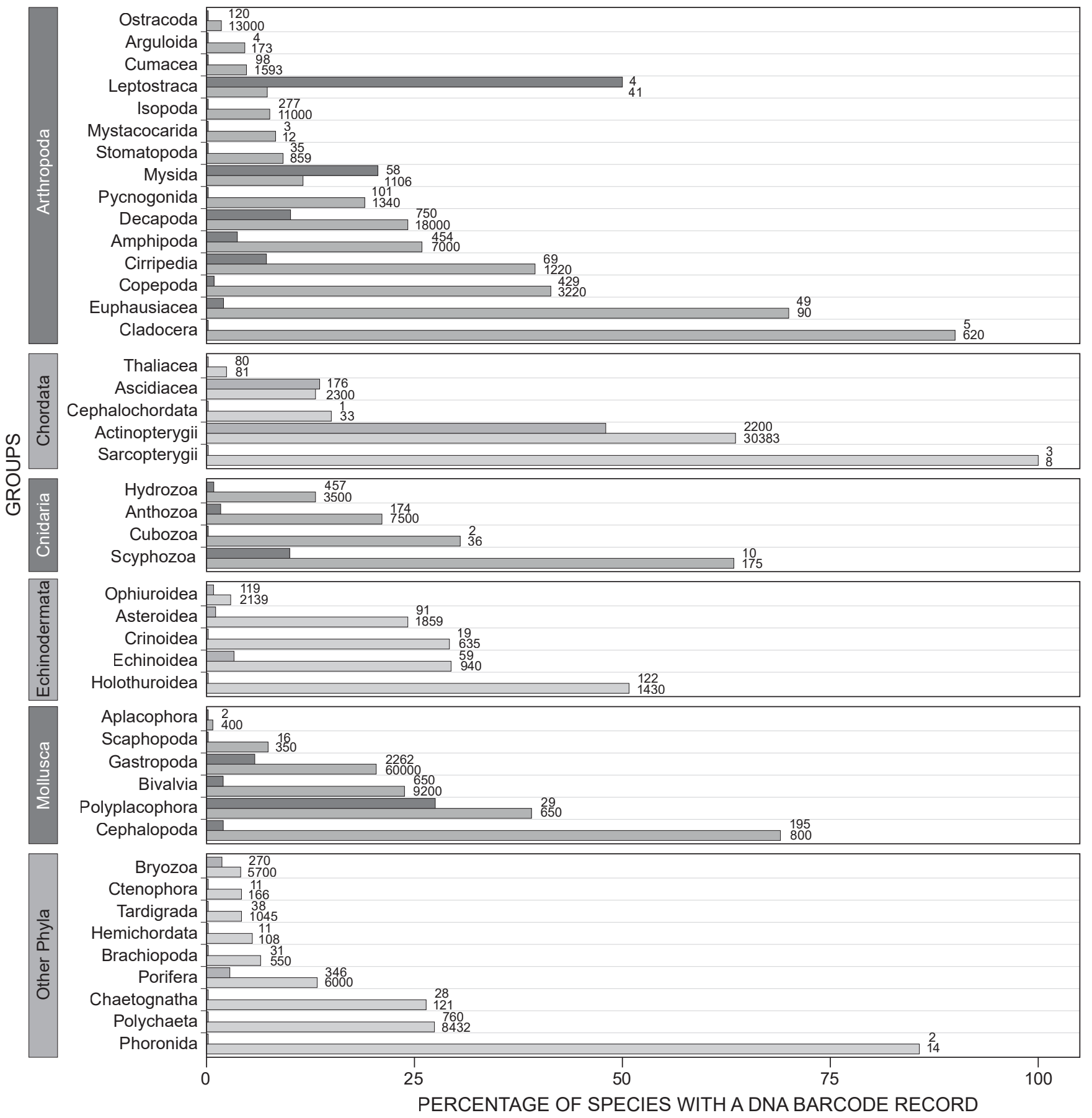

Figure 1: The relative percentages of DNA barcode records available for marine zooplankton taxa, globally (pale grey bars) and for South Africa (dark grey bars). The numbers of species known globally and locally are indicated next to the bars. Groups without known representatives in South Africa are not shown

species $(21 \%)$ and lesser proportions of bathydemersal, benthopelagic, bathypelagic, pelagic-neritic and pelagicoceanic species (Figure 2). Reef-associated and nearshore demersal species are more accessible to recreational and small-scale commercial fishers, from which samples for barcoding can easily be obtained. Access to specimens in the other habitat categories is limited because of depth or distance from shore, which reduces sampling opportunities.
Increasing difficulty in obtaining specimens from deeper waters also explains the depth trend, in which most barcoded fish originated from shallow waters $(37 \%$ in the $1-50 \mathrm{~m}$ depth range), decreasing to $14-17 \%$ with increasing depth in the $51-500 \mathrm{~m}$ depth range, $8 \%$ in the range $501-1000 \mathrm{~m}$, and $4 \%$ of species occurring deeper than $1000 \mathrm{~m}$. Fish occurring at depths of $>500 \mathrm{~m}$ are generally inaccessible to researchers without access to large research ships, or 


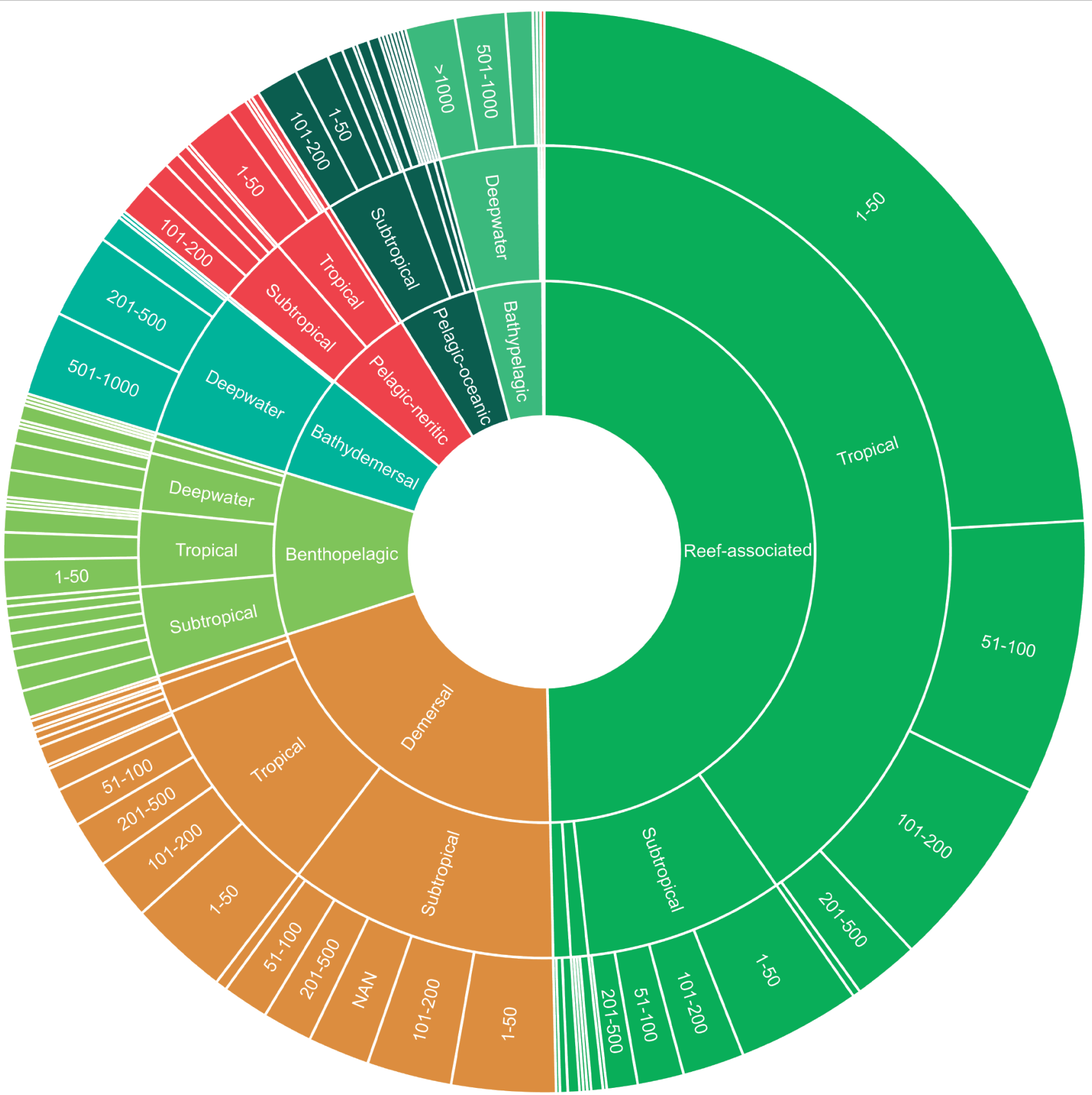

Figure 2: DNA barcode representation of South African marine fish taxa categorised according to habitat (demersal, benthopelagic, bathydemersal, pelagic-neritic, pelagic-oceanic, bathypelagic or reef-associated), biogeographic region (tropical, subtropical, deepwater) and maximum depth range (1-50 m, 51-100 m, 101-200 m, 201-500 m, 501-1000 m or >1 $000 \mathrm{~m}$ ). NAN indicates unknown depth

sampling of bycatches sourced from commercial deep-water trawlers. Tropical species made up $51 \%$ of barcode records, followed by subtropical species (31\%), deep-water species $(15 \%)$, and temperate-water species $(2 \%)$.

Commercially important fish species were the best-represented group in barcode records from South Africa $(73 \%$ of all marine fish records), whereas the remaining $27 \%$ were listed as having no commercial, recreational or subsistence importance (www.fishbase.org). Large-bodied decapods (lobsters, prawns, crabs) have high unit value on seafood markets and are popular species in recreational fisheries (Branch et al. 2010; DAFF 2016). A total of 10 out of 17 lobsters (59\%) with commercial or recreational importance had representative DNA barcodes from South Africa, and one species had no DNA barcode at all (Table 1). Two of 8 prawn species $(25 \%)$ and 5 of 8 commercially fished crabs $(63 \%)$ had barcode records from South Africa. These proportions were much higher than for all decapods from South Africa combined-10\% of fished and unfished species. Except for blood-spotted abalone Haliotis spadicae, all gastropods and bivalves with commercial interest in South Africa had representative 
Table 1: Availability of barcodes for crustacean and mollusc species important to commercial, recreational and/or artisanal fisheries in South Africa. Species marked with an asterisk ( $\left.{ }^{*}\right)$ have no known barcode globally. Importance in catches is denoted as target species, bycatch, or rarely caught. Some species are caught both by commercial and recreational fisheries but are listed only once (after Branch et al. 2010; DAFF 2016). Square brackets denote records not yet made public at the time of writing

\begin{tabular}{|c|c|c|c|c|}
\hline Type of fishery & Importance in catches & Species & Family & Barcode record \\
\hline \multirow[t]{10}{*}{ Commercial trap } & \multirow[t]{3}{*}{ Target } & Jasus lalandii & Palinuridae & Yes \\
\hline & & Palinurus delagoae & & Yes \\
\hline & & Palinurus gilchristi & & Yes \\
\hline & \multirow[t]{2}{*}{ Bycatch } & Scyllarides elisabethae & Scyllaridae & Yes \\
\hline & & ${ }^{*}$ Octopus magnificus & Cephalopoda & No \\
\hline & \multirow[t]{5}{*}{ Rare } & Linuparus somniosus & Palinuridae & No \\
\hline & & Palinustus unicornutus & & No \\
\hline & & ${ }^{*}$ Palinustus mossambicus & & No \\
\hline & & Puerulus angulatus & & No \\
\hline & & Projasus parkeri & & No \\
\hline \multirow[t]{16}{*}{ Commercial trawl } & \multirow[t]{5}{*}{ Target } & Metanephrops mozambicus & Nephropidae & Yes \\
\hline & & Fenneropenaeus indicus & Penaeidae & No \\
\hline & & Metapenaeus monoceros & & No \\
\hline & & Haliporoides triarthrus & Solenoceridae & No \\
\hline & & Chaceon macphersoni & Geryonidae & [Yes] \\
\hline & \multirow[t]{11}{*}{ Bycatch } & Ibacus novemdentatus & Scyllaridae & Yes \\
\hline & & Nephropsis stewarti & Nephropidae & Yes \\
\hline & & Penaeus monodon & Penaeidae & Yes \\
\hline & & Penaeus japonicus & & No \\
\hline & & Penaeus semisulcatus & & No \\
\hline & & Aristaeomorpha foliacea & Aristeidae & No \\
\hline & & Aristeus antennatus & & No \\
\hline & & Chaceon maritae & Geryonidae & No \\
\hline & & Sepia officianalis & Cephalopoda & No \\
\hline & & *Veladona togata & & No \\
\hline & & Uroteuthis duvaucelii & & No \\
\hline \multirow{2}{*}{$\begin{array}{l}\text { Commercial diving or } \\
\text { jig fishing }\end{array}$} & \multirow[t]{2}{*}{ Target } & Haliotis midae & Gastropoda & Yes \\
\hline & & Loligo reynaudii & Cephalopoda & No \\
\hline \multirow[t]{23}{*}{ Recreational and artisanal } & \multirow[t]{17}{*}{ Target } & Panulirus homarus & Palinuridae & Yes \\
\hline & & Scylla serrata & Portunidae & Yes \\
\hline & & Portunus pelagicus & & No \\
\hline & & Portunus sanguinolentus & & Yes \\
\hline & & ${ }^{*}$ Callianassa kraussi & Callianassidae & No \\
\hline & & Upogebia africana & Upogebiidae & Yes \\
\hline & & Ovalipes trimaculatus & Ovalipidae & Yes \\
\hline & & Perna perna & Bivalvia & Yes \\
\hline & & Striostrea margaritacea & & Yes \\
\hline & & Saccostrea cuccullata & & Yes \\
\hline & & Mytilus galloprovincialis & & Yes \\
\hline & & Choromytilus meridionalis & & [Yes] \\
\hline & & Donax serra & & [Yes] \\
\hline & & Cymbula oculus & Gastropoda & Yes \\
\hline & & ${ }^{*}$ Haliotis spadicae & & No \\
\hline & & Turbo sarmaticus & & Yes \\
\hline & & Octopus vulgaris & Cephalopoda & Yes \\
\hline & Bycatch & Turbo coronatus & Gastropoda & [Yes] \\
\hline & \multirow[t]{5}{*}{ Rare } & Panulirus versicolor & Palinuridae & Yes \\
\hline & & Panulirus longipes & & Yes \\
\hline & & Panilurus ornatus & & No \\
\hline & & Panilurus penicillatus & & No \\
\hline & & Fissurella natalensis & Gastropoda & Yes \\
\hline
\end{tabular}

DNA barcode records from South Africa, although three of them were not publicly available at the time of writing (Table 1 ). Global DNA barcode records were available for 4 of 6 commercially important cephalopods (67\%); 1 cephalopod had a representative DNA barcode from South Africa, and 2 species had no DNA barcode record at all on BOLD.

\section{Invasive species}

The geographical spread of invasive marine invertebrates can be traced visually, but their larval phases disperse in the zooplankton, where metabarcoding is a powerful tool of discovery. We listed the DNA barcode availability of 76 alien invasive species (introduced or cryptogenic) expected 
Table 2: List of known invasive species expected to be in the zooplankton in South Africa according to Mead et al. (2011) and Robinson et al. (2016), and availability of DNA barcode records. Square brackets denote records not yet made public at the time of writing

\begin{tabular}{|c|c|c|c|}
\hline Phylum & Species & Global record & South African record \\
\hline Porifera & Suberites ficus & Yes & No \\
\hline \multirow[t]{13}{*}{ Cnidaria } & Metridium senile & Yes & No \\
\hline & Sagartia ornata & Yes & No \\
\hline & Pachycordyle navis & No & No \\
\hline & Coryne eximia & Yes & Yes \\
\hline & Odessia maeotica & No & No \\
\hline & Pennaria disticha & Yes & No \\
\hline & Ectopleura larynx & Yes & No \\
\hline & Ectopleura crocea & Yes & No \\
\hline & Laomedea calceolifera & Yes & No \\
\hline & Gonothyraea loveni & Yes & No \\
\hline & Obelia bidentata & Yes & No \\
\hline & Obelia dichotoma & Yes & No \\
\hline & Obelia geniculata & Yes & No \\
\hline \multirow[t]{9}{*}{ Annelida } & Boccardia proboscidea & Yes & No \\
\hline & Alitta succinea & Yes & No \\
\hline & Polydora hoplura & Yes & No \\
\hline & Dodecaceria fewkesi & Yes & No \\
\hline & Ficopomatus enigmaticus & Yes & [Yes] \\
\hline & Polydora cf. websteri & Yes & No \\
\hline & Neodexiospira brasiliensis & [Yes] & No \\
\hline & Janua pagenstecheri & No & No \\
\hline & Simplaria pseudomilitaris & No & No \\
\hline \multirow[t]{24}{*}{ Crustacea } & Balanus glandula & Yes & Yes \\
\hline & Austrominius modestus & Yes & No \\
\hline & Amphibalanus venustus & No & No \\
\hline & Acartia spinicauda & Yes & No \\
\hline & Dynamene bidentata & Yes & No \\
\hline & Sphaeroma serratum & Yes & No \\
\hline & Sphaeroma walkeri & No & No \\
\hline & Paracerceis sculpta & Yes & No \\
\hline & Limnoria quadripunctata & Yes & No \\
\hline & Limnoria tripunctata & No & No \\
\hline & Chelura terebrans & [Yes] & No \\
\hline & Ischyrocerus anguipes & Yes & No \\
\hline & Ericthonius brasiliensis & Yes & No \\
\hline & Ericthonius difformis & Yes & No \\
\hline & Monocorophium acherusicum & Yes & No \\
\hline & Jassa marmorata & Yes & No \\
\hline & Jassa morinoi & Yes & No \\
\hline & Jassa slatteryi & Yes & No \\
\hline & Orchestia gammarellus & Yes & No \\
\hline & Platorchestia platensis & Yes & Yes \\
\hline & Cerapus tubularis & [Yes] & No \\
\hline & Carcinus maenas & Yes & No \\
\hline & Xantho incisus & Yes & No \\
\hline & Ammothella appendiculata & Yes & No \\
\hline \multirow[t]{11}{*}{ Mollusca } & Littorina saxatilis & Yes & [Yes] \\
\hline & Indothais blanfordi & Yes & No \\
\hline & Semiricinula tissoti & Yes & No \\
\hline & Tarebia granifera & Yes & [Yes] \\
\hline & Catriona columbiana & No & No \\
\hline & Mytilus galloprovincialis & Yes & [Yes] \\
\hline & Crassostrea gigas & Yes & [Yes] \\
\hline & Perna viridis & Yes & [Yes] \\
\hline & Semimytilus algosus & Yes & [Yes] \\
\hline & Teredo navalis & Yes & No \\
\hline & Lyrodus pedicellatus & Yes & No \\
\hline Brachiopoda & Discinisca tenuis & No & No \\
\hline
\end{tabular}


Table 2: (cont.)

\begin{tabular}{llcc}
\hline Phylum & Species & Global record & South African record \\
\hline Bryozoa & Watersipora subtorquata & Yes & Yes \\
& Bugula neritina & Yes & Yes \\
& Bugula flabellata & Yes & Yes \\
& Bugula dentata & Yes & No \\
& Conopeum seurati & {$[$ Yes] } & No \\
& Cryptosula pallasiana & Yes & No \\
\hline Echinodermata & Ophiactis savignyi & Yes & No \\
\hline Chordata & Clavelina lepadiformis & Yes & No \\
& Diplosoma listerianum & Yes & No \\
& Ciona intestinalis & Yes & No \\
& Ascidia sydneiensis & Yes & No \\
& Ascidiella aspersa & Yes & No \\
& Botryllus schlosseri & Yes & No \\
& Cnemidocarpa humilis & No & No \\
& Styela plicata & Yes & No \\
& Microcosmus squamiger & Yes & Yes \\
& Cyprinus carpio & Yes & \\
\hline
\end{tabular}

to occur in the zooplankton in South African marine and estuarine environments (Mead et al. 2011; Robinson et al. 2016) (Table 2). Ten species in the global record did not have DNA barcode records, and 4 species had DNA barcode records which were not yet public. Fourteen species had DNA barcode records originating from South Africa (13\%), of which 7 species were not publicly available. Bezeng and van der Bank (2019) compiled a DNA barcode reference database for southern African crustaceans, which also included alien invasive species (25 specimens of 5 unique species, to date).

\section{Metabarcoding of zooplankton samples}

Sorting of plankton tow-net samples based on microscopic examination of morphological characteristics showed that copepods were the most abundant, followed by malacostracans (decapods, amphipods, isopods, mysids, cumaceans) and gastropods (Figure 3a). These three groups, together with ray-finned fish larvae (Actinopterygii) and chaetognath arrow worms (Sagittoidea) were recovered in all 13 samples analysed, whereas barnacles (Cirripedia), Cephalopoda, Brachiopoda and the Cladocera were rarer and found in less than five of the samples analysed microscopically (Figure 3b).

Metabarcoding of a pooled sample found 270 ASVs, of which $123(45.6 \%)$ could be assigned to species level using the BOLD identification engine and a threshold of $95 \%$ similarity, compared with 122 species (45.2\%) using GenBank, and 114 species $(42.2 \%)$ using the MIDORI classifier. Taxa with most ASVs were Malacostraca, Copepoda, Hydrozoa, Gastropoda and Actinopterygii, with fewer species in other groups (Figure 4a). The highest number of ASVs belonged to the Malacostraca (80 ASVs) (Figure 4a), of which $>20 \%$ could be assigned to species level, followed by the Copepoda (72 ASVs), of which $>50 \%$ could be assigned to species level. Out of a total of 162 ASVs recovered from metabarcoding of a single tow-net sample, BOLD assigned 77 (47.5\%) to species level, GenBank assigned 69 (42.6\%), and MIDORI assigned $64(39.5 \%)$. Groups recovered from the single tow-net sample were similar to those in the pooled sample, with minor exceptions.

\section{Discussion}

Recent advances in metabarcoding have revolutionised zooplankton biodiversity research worldwide by facilitating rapid, accurate and high-resolution analysis of taxonomically complex samples (Laakmann et al. 2020; Questel et al. 2021). Metabarcoding technology enables many new research opportunities and applications, from assessments of the 'hidden biodiversity' in marine pelagic ecosystems (Lindeque et al. 2013; Leray and Knowlton 2016) to ecological studies of zooplankton assemblages (Critescu 2014) and long-term biomonitoring and environmental status assessments of pelagic ecosystems (Aylagas et al. 2014; Govender 2021). Metabarcoding of zooplankton is new in South Africa and our study documents the initial steps in its application, including potential pitfalls and prospects (see Bucklin et al. 2016).

DNA barcodes of most South African marine species were mined from GenBank in our study, suggesting that the barcodes were originally sourced from research that did not entail classical DNA barcoding studies. Metadata such as location or country of collection, collectors or collecting institute were not always provided on records. A crucial shortcoming of data exchange between BOLD and GenBank is that BOLD only imports COI sequence records from GenBank that have a 'country' feature (da Silva and Willows-Munro 2016). Contributions of South African DNA barcode records to BOLD would most likely scale up if these metadata were included in GenBank submissions. Robust sequence-data annotation standardised across the different databases is therefore required for accurate representation of records, or DNA barcoding data could be submitted directly to BOLD instead of added to GenBank.

The numbers/proportions of barcoded species per taxon shown in this study were approximations only, because they relied on estimates of individual studies, undertaken at 

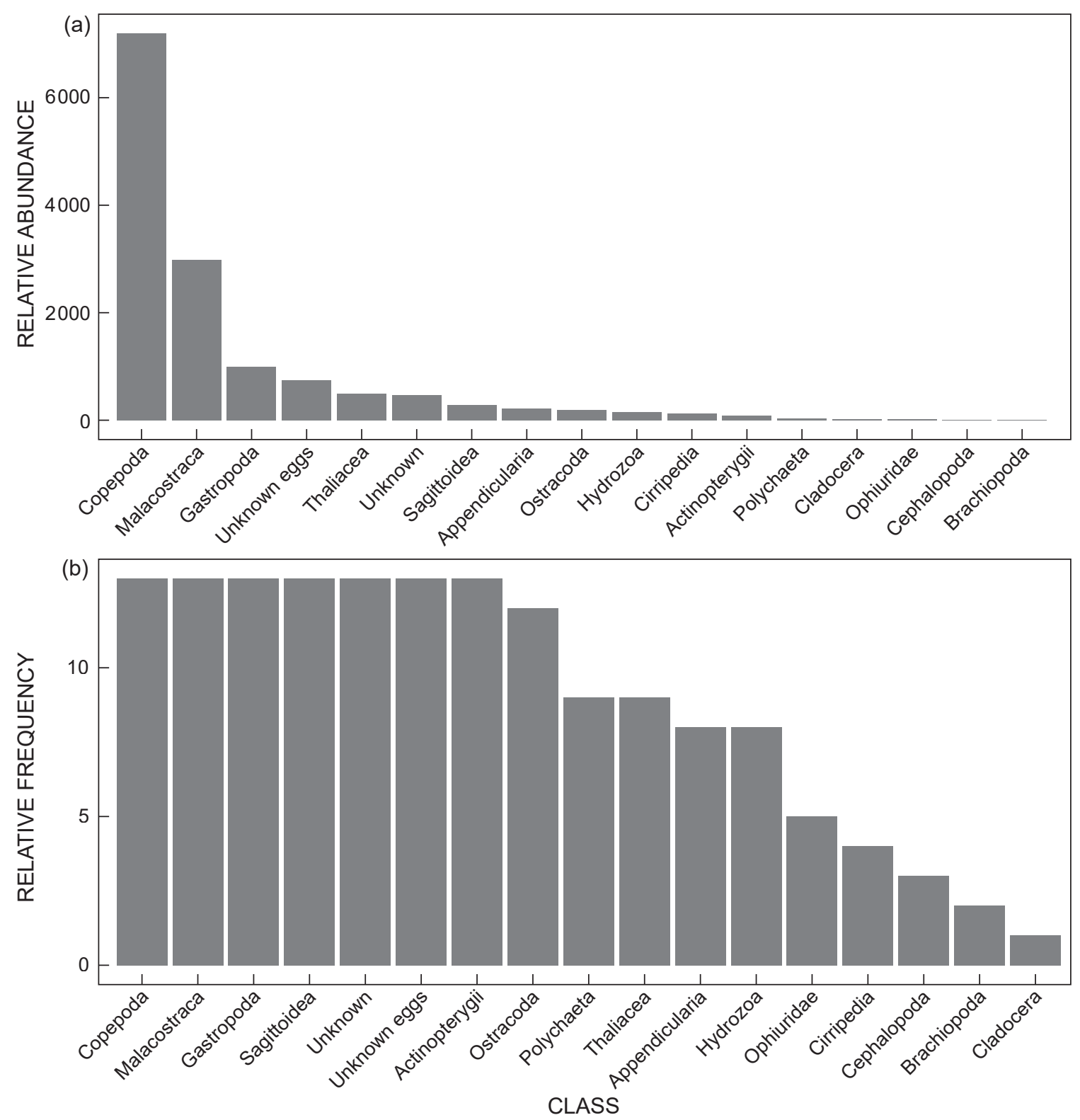

Figure 3: (a) Relative abundance (number of individuals from each class found in a sample) and (b) relative frequency (per sample occurrence of an organism from each class) of zooplankton taxa, ordered by class, from 13 zooplankton community samples collected over the continental shelf of KwaZulu-Natal, South Africa

different times and places, and would have been influenced by taxonomic revisions or differences in the systematic classification used. Furthermore, records were extracted from online databases in January 2019, and given the rapid growth of DNA barcoding records, the numbers of barcoded species increase continuously. Nevertheless, our study was intended as a relative benchmark only, to indicate gaps in barcode reference databases. Even so, the study took place at an important juncture-the crossover from microscopy to genes in marine biodiversity studies (Laakmann et al. 2020) and at the onset of metabarcoding initiatives in South Africa.

Analysis of DNA barcoding records from South Africa highlighted two clear trends: in nearly all taxonomic groups there are proportionally fewer records of known species than are available on global datasets; and, there is a preponderance of barcodes for meroplanktonic taxa with large benthic or pelagic adult stages, especially those with commercial or recreational value. These trends partially reflect local research opportunities and the logistics of sampling, namely physical accessibility (by depth, habitat or distance from shore) and the availability of specialist sampling equipment (which is costly, especially for offshore sampling), as well as taxonomic expertise (scarce in most taxa, especially in groups without commercial value). For example, ray-finned fishes were numerically and proportionally the best-represented taxon from South Africa and on par with global barcoding efforts. Fishes in South Africa have high diversity and rates of endemism 


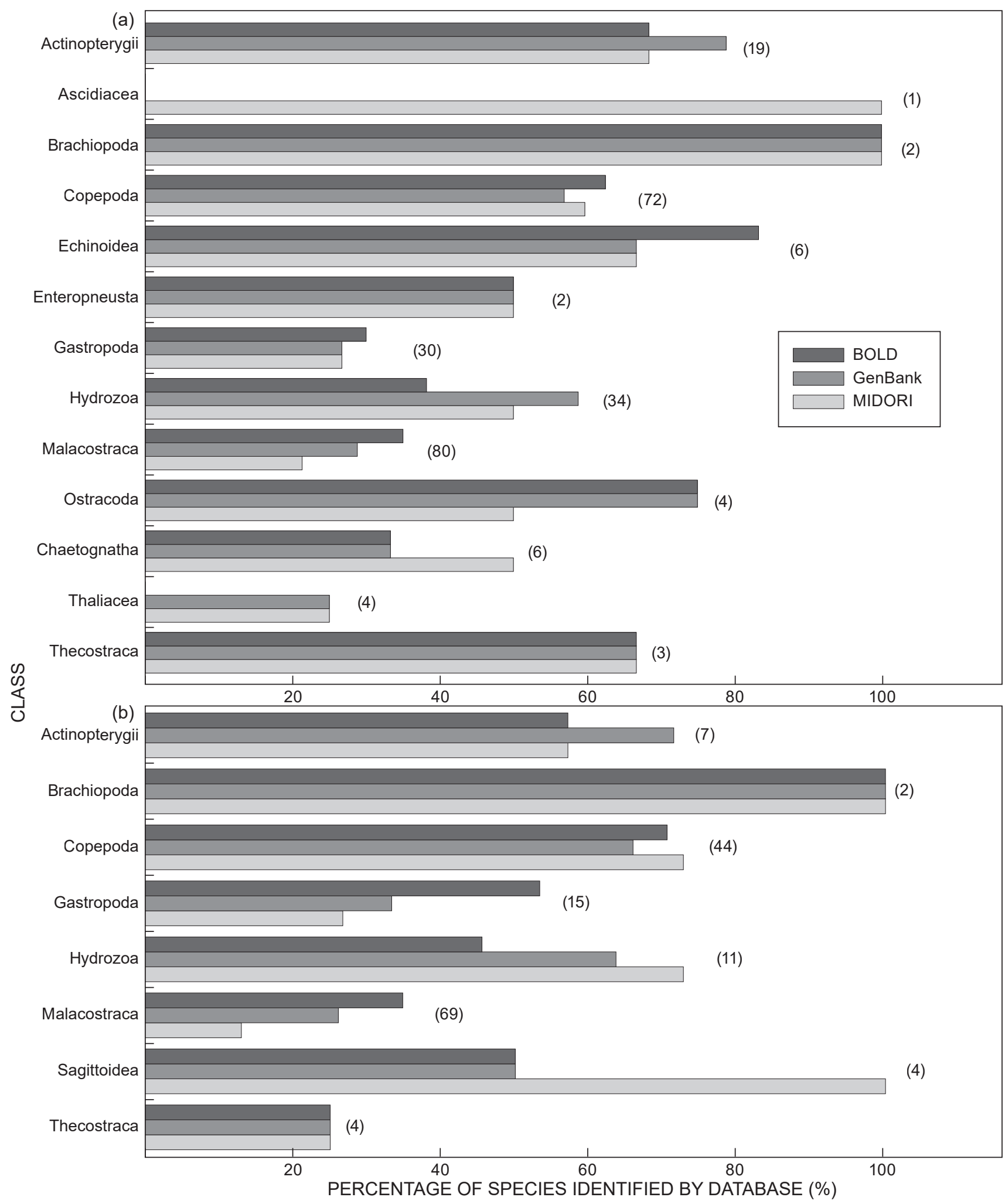

Figure 4: The percentage of amplified sequence variants (ASVs) detected by DNA metabarcoding that could be assigned to species level using the BOLD identification engine, GenBank, and the MIDORI classifier, with a threshold of $>95 \%$ similarity per class, for (a) the pooled sample, and (b) a single tow-net sample. In panel 'a', Ascidiacea, Bivalvia, Cephalopoda and Tentaculata were present but are not included in the graph because none could be identified to species level. In panel 'b', Bivalvia, Enteropneusta and Ostracoda were present but are not included in the graph because they could not be identified to species level. The total number of unique ASVs from each group is given in parenthesis 
(36\%: Griffiths and Robinson 2016), many species have commercial and recreational value, and they are easy to sample as adults-hence, they have been popular candidates in DNA barcoding studies (Steinke et al. 2016). For the same reasons, most commercially important decapods had barcodes, but those without commercial importance were poorly represented locally when compared with globally. Barcode records of other meroplanktonic and nearly all holoplanktonic taxa, which make up the bulk of oceanic diversity, lagged well behind global barcoding efforts. Overall, the zooplankton barcode record from South Africa supports the concerns of Blaxter (2003) that reference databases are biased towards large, easy to find and identify, commercially important taxa, which comprise only a small proportion of marine biodiversity.

Zooplankton are integral in marine food webs because they function as both consumers and producers (i.e. food) for other organisms (Marine Zooplankton Colloquium 2001). Many species are short-lived and their physiological processes and population dynamics are highly temperaturedependent, making them good indicators of environmental change (Hays et al. 2005; Richardson 2008; Greene and Pershing 2012). The sparse barcode reference databases for smaller holoplanktonic taxa are therefore an impediment to the development of community-based indices of change in marine biodiversity, based on metabarcoding. Key holoplanktonic groups (copepods, euphausiids and amphipods, among others) (see Supplementary Table S1) all lack comprehensive DNA barcodes from South Africa. Similar to the findings of Fisher et al. (2010), our study indicates a mismatch between present barcode reference databases and future metabarcoding objectives, which can be overcome by fast-tracking integrative molecular/ morphology studies to increase the numbers of taxonomic records in key holoplanktonic taxa.

Establishing integrative taxonomic approaches for zooplankton research in South Africa is a key factor in accurately distinguishing between similar-looking species in mixed samples (Sabatini et al. 2007; Bradford-Grieve et al. 2017; Höring et al. 2017), especially for abundant taxa with high ecological importance such as copepods and euphausiids (krill), which can periodically dominate zooplankton biomass (Bucklin et al. 2007). The importance of foundational DNA barcoding projects in South Africa, in which reference specimens are retained and photographed, with barcodes submitted to BOLD, is recognised by the Foundational Biodiversity Information Programme (FBIP, https://fbip.co.za) funded by the South African Department of Science and Technology and managed by the National Research Foundation (NRF) and the South African National Biodiversity Institute (SANBI).

Metabarcoding of plankton tow-net samples collected on the east coast of South Africa showed that approximately $45 \%$ of the ASVs encountered could be assigned to species level using $\mathrm{COI}$, irrespective of reference database searched (i.e. BOLD, GenBank or MIDORI COI classifier). Metabarcoding could identify 123 species in a pooled sample (using the BOLD identification engine and a threshold of 95\% similarity) and 77 species in a single tow-net sample. Using a single plankton tow as a sample may therefore underestimate zooplankton diversity, because of spatial patchiness of zooplankton assemblages (Omori and Hamner 1982). Morphological analysis of samples could not achieve comparable resolution at species level, but with some exceptions it recovered classes of organisms similar to those identified through metabarcoding. Differences in the results obtained were that morphological identification picked up three groups (Brachiopoda, Ophiuridae and Cirripedia) not identified by metabarcoding, whereas metabarcoding detected Echinoidea and Enteropneusta, which were not identified by morphological analysis. Importantly, species identification of zooplankton using morphological characteristics is a highly specialised task, and taxonomic identification keys are incomplete for larval stages of many taxa. Matching the composition of zooplankton samples obtained from metabarcoding with those obtained from traditional microscopy is therefore unreliable at species level but improves at class level.

\section{Conclusions}

The DNA barcode data analysed in this study highlighted that barcode reference databases for marine zooplankton are incomplete and that holoplankton are underrepresented in barcode databases. The need for integrative molecular/ morphological studies to increase and validate barcode reference databases of key zooplankton classes is recognised and will improve the resolution and representivity of metabarcoding outputs. Metabarcoding of marine zooplankton in South Africa has now been successfully applied as a pilot project, and the methodology is poised to: (i) shift research emphasis from individual species to assemblages (see Laakmann et al. 2020); (ii) facilitate high-resolution monitoring of zooplankton biodiversity in pelagic ecosystems; and (iii) accelerate the discovery of new species.

Acknowledgements - We thank the South African Department of Science and Technology (DST) and the National Research Foundation (NRF) for funding the ACEP Captor Project (grant 110763), and the Economic Development, Tourism and Environmental Affairs (EDTEA) Department of KwaZulu-Natal Province for operational funding. The first author (SS) was supported by a SARChl Post-Doctoral Fellowship awarded by the NRF. We thank the South African Institute for Aquatic Biodiversity (SAIAB) for use of the RV Phakisa and its crew to collect samples at sea, and the KwaZulu-Natal Research Innovation and Sequencing Platform (KRISP) team for carrying out NGS on the Illumina MiSeq platform, from which a small portion of data was used. Two peer-reviewers are thanked for many constructive comments on the initial draft.

\section{ORCID}

Riaan Cedras: https://orcid.org/0000-0003-0562-4173 Johan Groeneveld: https://orcid.org/0000-0002-9831-9073

Jenny Huggett: https://orcid.org/0000-0001-9315-8672

Diandra Naidoo: https://orcid.org/0000-0002-4516-0417

Sohana Singh: https://orcid.org/0000-0003-3484-7800

Sandi Willows-Munro: https://orcid.org/0000-0003-0572-369X

\section{References}

Aylagas E, Borja Á, Rodríguez-Ezpeleta N. 2014. Environmental status assessment using DNA metabarcoding: towards a 
genetics-based marine biotic index (gAMBI). PLOS ONE 9: e90529.

Berry PF. 1974. Palinurid and Scyllarid lobster larvae of the Natal Coast, South Africa. Investigational Report No. 34. Durban, South Africa: Oceanographic Research Institute.

Bezeng BS, van der Bank HF. 2019. DNA barcoding of southern African crustaceans reveals a mix of invasive species and potential cryptic diversity. PLOS ONE 14: e0222047.

Blaxter M. 2003. Molecular systematics - counting angels with DNA. Nature 421: 122-124.

Bolyen E, Rideout JR, Dillon MR, Bokulich NA, Abnet CC, Al-Ghalith GA et al. 2019. Reproducible, interactive, scalable and extensible microbiome data science using QIIME 2. Nature Biotechnology 37: 848-857.

Bradford-Grieve JM, Blanco-Bercial L, Prusova I. 2017. Calanoides natalis Brady, 1914 (Copepoda: Calanoida: Calanidae): identity and distribution in relation to coastal oceanography of the eastern Atlantic and western Indian Oceans. Journal of Natural History 51: 807-836.

Branch GM, Griffiths CL, Branch ML, Beckley LE. 2010. Two oceans: a guide to the marine life of southern Africa. Cape Town, South Africa: Struik.

Brierley AS. 2017. Plankton. Current Biology 27: R478-R483.

Bucklin A, Wiebe PH, Smolenack SB, Copley NJ, Beaudet JG, Bonner KG et al. 2007. DNA barcodes for species identification of euphausiids (Euphausiacea, Crustacea). Journal of Plankton Research 29: 483-493.

Bucklin A, Steinke D, Blanco-Bercial L. 2011. DNA barcoding of marine metazoa. Annual Review of Marine Science 3: 471-508.

Bucklin A, Lindeque PK, Rodriguez-Ezpeleta N, Albaina A, Lehtiniemi M. 2016. Metabarcoding of marine zooplankton: prospects, progress and pitfalls. Journal of Plankton Research 38: 393-400.

Callahan BJ, McMurdie PJ, Rosen MJ, Han AW, Johnson AJA, Holmes SP. 2016. DADA2: high-resolution sample inference from Illumina amplicon data. Nature Methods 13: 581-583.

Carroll EL, Gallego R, Sewell MA, Zeldis J, Ranjard L, Ross HA et al. 2019. Multi-locus DNA metabarcoding of zooplankton communities and scat reveal trophic interactions of a generalist predator. Scientific Reports 9: article 281.

Casas L, Pearman JK, Irigoien X. 2017. Metabarcoding reveals seasonal and temperature-dependent succession of zooplankton communities in the Red Sea. Frontiers in Marine Science 4: article 241.

Chamberlain S. 2018. bold: Interface to Bold Systems API. Available at https://rdrr.io/cran/bold/ [accessed January 2018].

Cristescu ME. 2014. From barcoding single individuals to metabarcoding biological communities: towards an integrative approach to the study of global biodiversity. Trends in Ecology and Evolution 29: 566-571.

DAFF (Department of Agriculture, Forestry and Fisheries). 2016. Status of the South African marine fishery resources 2016. Cape Town, South Africa: DAFF. Available at https://www.environment. gov.za/sites/default/files/reports/statusofsouthafrican_ marinefisheryresources2016.pdf.

da Silva JM, Willows-Munro S. 2016. A review of over a decade of DNA barcoding in South Africa: a faunal perspective. African Zoology 51: 1-12.

Djurhuus A, Pitz K, Sawaya NA, Rojas-Márquez J, Michaud B, Montes E et al. 2018. Evaluation of marine zooplankton community structure through environmental DNA barcoding. Limnology and Oceanography: Methods 16: 209-221.

Dormontt EE, van Dijk K, Bell KL, Biffin E, Breed MF, Byrne M et al. 2018. Advancing DNA barcoding and metabarcoding applications for plants requires systematic analysis of herbarium collections - an Australian perspective. Frontiers in Ecology and Evolution 6: article 134.
Fisher R, Radford BT, Knowlton N, Brainard RE, Michaelis FB, Caley MJ. 2010. Global mismatch between research effort and conservation needs of tropical coral reefs. Conservation Letters 4: 64-72.

Folmer O, Black M, Hoeh W, Lutz R, Vrijenhoek R. 1994. DNA primers for amplification of mitochondrial cytochrome $\mathrm{c}$ oxidase subunit I from diverse metazoan invertebrates. Molecular Marine Biology and Biotechnology 3: 294-299.

Francis CM, Borisenko AV, Ivanova NV, Eger JL, Lim BK, Guillén-Servent A et al. 2010. The role of DNA barcodes in understanding and conservation of mammal diversity in Southeast Asia. PLoS ONE 5: e12575.

Goetze E. 2010. Species discovery in marine planktonic invertebrates through global molecular screening. Molecular Ecology 19: 952-967.

Govender A. 2021. DNA metabarcoding of zooplankton enhances community-level analyses of connectivity in a marine pelagic environment. PhD thesis, University of KwaZulu-Natal, South Africa.

Govender A, Groeneveld J, Singh S, Willows-Munro S. 2019. The design and testing of mini-barcode markers in marine lobsters. PLOS ONE 14: e0210492

Greene $\mathrm{CH}$, Pershing AJ. 2012. Climate drives sea change. Science 315: 1084-1085.

Griffiths CL, Robinson TB. 2016. Use and usefulness of measures of marine endemicity in South Africa. South African Journal of Science 112: article 2015-0249.

Griffiths CL, Robinson TB, Lange L, Mead A. 2010. Marine biodiversity in South Africa: an evaluation of current states of knowledge. PLOS ONE 5: e12008.

Hajibabaei M, Janzen DH, Burns JM, Hallwachs W, Hebert PDN. 2006. DNA barcodes distinguish species of tropical Lepidoptera. Proceedings of the National Academy of Sciences of the United States of America 103: 968-971.

Hays GC, Richardson AJ, Robinson C. 2005. Climate change and marine plankton. Trends in Ecology and Evolution 20: 337-344.

Hebert PDN, Cywinska A, Ball SL, deWaard JR. 2003. Biological identifications through DNA barcodes. Proceedings of the Royal Society B: Biological Sciences 270: 313-321.

Hebert PDN, Stoeckle MY, Zemlak TS, Francis CM. 2004. Identification of birds through DNA barcodes. PLoS Biology 2: e312.

Hirai J, Tachibana A, Tsuda A. 2020. Large-scale metabarcoding analysis of epipelagic and mesopelagic copepods in the Pacific. PLOS ONE 15: e0233189.

Höring F, Cornils A, Auel H, Bode M, Held C. 2017. Population genetic structure of Calanoides natalis (Copepoda, Calanoida) in the eastern Atlantic Ocean and Benguela upwelling system. Journal of Plankton Research 39: 618-630.

Huggett JA, Verheye HM, Escribano R, Fairweather T. 2009. Copepod biomass, size composition and production in the Southern Benguela: spatio-temporal patterns of variation, and comparison with other eastern boundary upwelling systems. Progress in Oceanography 83: 197-207.

Hutchings L, Jarre A, Lamont T, van den Berg M, Kirkman SP. 2012. St Helena Bay (southern Benguela) then and now: muted climate signals, large human impact. African Journal of Marine Science 34: 559-583.

Jarre A, Hutchings L, Kirkman SP, Kreiner A, Tchipalanga PCM, Kainge $P$ et al. 2015. Synthesis: climate effects on biodiversity, abundance and distribution of marine organisms in the Benguela. Fisheries Oceanography 24: 122-149.

Ko HL, Wang YT, Chiu TS, Lee MA, Leu MY, Chang KZ et al. 2013. Evaluating the accuracy of morphological identification of larval fishes by applying DNA barcoding. PLOS ONE 8: e53451.

Knolt KE, Balser EJ, Jaeckle WB, Wray GA. 2003. Identification of asteroid genera with species capable of larval cloning. Biological Bulletin 204: 246-255. 
Laakmann S, Blanco-Bercial L, Cornils A. 2020. The crossover from microscopy to genes in marine diversity: from species to assemblages in marine pelagic copepods. Philosophical Transactions of the Royal Society B: Biological Sciences 375: 20190446.

Leis JM. 2015. Taxonomy and systematics of larval Indo-Pacific fishes: a review of progress since 1981. Ichthyological Research 62: 9-28.

Leray M, Knowlton N. 2015. DNA barcoding and metabarcoding of standardized samples reveal patterns of marine benthic diversity. Proceedings of the National Academy of Sciences of the United States of America 112: 2076-2081.

Leray M, Knowlton N. 2016. Censusing marine eukaryotic diversity in the twenty-first century. Philosophical Transactions of the Royal Society B: Biological Sciences 371: 20150331.

Leray M, Yang JY, Meyer CP, Mills SC, Agudelp N, Ranwez V et al. 2013. A new versatile primer set targeting a short fragment of the mitochondrial $\mathrm{COI}$ region for metabarcoding metazoan diversity: application for characterizing coral reef fish gut contents. Frontiers in Zoology 10: article 34.

Leray M, Ho SL, Lin IJ, Machida RJ. 2018. MIDORI server: a webserver for taxonomic assignment of unknown metazoan mitochondrial-encoded sequences using a curated database. Bioinformatics 34: 3753-3754.

Lindeque PK, Parry HE, Harmer RA, Somerfield PJ, Atkinson A. 2013. Next generation sequencing reveals the hidden diversity of zooplankton assemblages. PLOS ONE 8: e81327.

Marine Zooplankton Colloquium. 2001. Future marine zooplankton research - a perspective. Marine Ecology Progress Series 222: 297-308.

Matsuda H, Sakai M, Yanagimoto T, Chow S. 2019. Morphological differences among phyllosoma larvae of the pronghorn spiny lobster, Panulirus penicillatus, from the western, central, and eastern areas of the Pacific Ocean. Crustacean Research 48: 105-118.

Mead A, Carlton JT, Griffiths CL, Rius M. 2011. Revealing the scale of marine bioinvasions in developing regions: a South African re-assessment. Biological Invasions 13: 1991-2008.

Omori M, Hamner WM. 1982. Patchy distribution of zooplankton: behavior, population assessment and sampling problems. Marine Biology 72: 193-200

Questel JM, Hopcroft RR, DeHart HM, Smoot CA, Kosobokova KN, Bucklin A. 2021. Metabarcoding of zooplankton diversity within the Chukchi Borderland, Arctic Ocean: improved resolution from multi-gene markers and region-specific DNA databases. Marine Biodiversity 51: article 4.

Richardson AJ. 2008. In hot water: zooplankton and climate change. ICES Journal of Marine Science 65: 279-295.

Robinson TB, Alexander ME, Simon CA, Griffiths CL, Peters K, Sibanda $S$ et al. 2016. Lost in translation? Standardizing the terminology used in marine invasion biology and updating South African alien species lists. African Journal of Marine Science 38: 129-140.
Rosenberg G. 2014. A new critical estimate of named species-level diversity of the recent Mollusca. American Malacological Bulletin 32: 308-322.

Sabatini ME, Ramírez FC, Bradford-Grieve J. 2007. Redescription of Calanoides carinatus (Krøyer) (Copepoda: Calanoida: Calanidae) with a discussion on the status of related species. Invertebrate Systematics 21: 341-364.

Shokralla S, Spall JL, Gibson JF, Hajibabaei M. 2012. Next-generation sequencing technologies for environmental DNA research. Molecular Ecology 21: 1794-1805.

Singh SP, Groeneveld JC, Al-Marzouqi A, Willows-Munro S. 2017. A molecular phylogeny of the spiny lobster Panulirus homarus highlights a separately evolving lineage from the Southwest Indian Ocean. PeerJ 5: e3356.

Singh SP, Groeneveld JC, Hart-Davis MG, Backeberg BC, WillowsMunro S. 2018. Seascape genetics of the spiny lobster Panulirus homarus in the Western Indian Ocean: understanding how oceanographic features shape the genetic structure of species with high larval dispersal potential. Ecology and Evolution 8: 12221-12237.

Steinke D, Connell AD, Hebert PDN. 2016. Linking adults and immatures of South African marine fishes. Genome 59: 959-967.

Taberlet P, Coissac E, Pompanon F, Brochmann C, Willerslev E. 2012. Towards next-generation biodiversity assessment using DNA metabarcoding. Molecular Ecology 21: 2045-2050.

Turner JT. 2015. Zooplankton fecal pellets, marine snow, phytodetritus and the ocean's biological pump. Progress in Oceanography 130: 205-248.

Vargas S, Schuster A, Sacher K, Büttner G, Schätzle S, Läuchli B et al. 2012. Barcoding sponges: an overview based on comprehensive sampling. PLoS ONE 7: e39345.

Verheye HM. 2000. Decadal-scale trends across several marine trophic levels in the southern Benguela upwelling system off South Africa. Ambio 29: 30-34.

Verheye HM, Hutchings L, Huggett JA, Painting SJ. 1992. Mesozooplankton dynamics in the Benguela ecosystem, with emphasis on the herbivorous copepods. In: Payne AlL, Brink KH, Mann $\mathrm{KH}$, Hilborn R (eds), Benguela trophic functioning. South African Journal of Marine Science 12: 561-584.

Verheye HM, Richardson AJ, Hutchings L, Marska G, Gianakouras D. 1998. Long-term trends in the abundance and community structure of coastal zooplankton in the southern Benguela system, 1951-1996. South African Journal of Marine Science 19: 317-332.

Verheye HM, Lamont T, Huggett JA, Kreiner A, Hampton I. 2016. Plankton productivity of the Benguela Current large marine ecosystem (BCLME). Environmental Development 17: 75-92.

Ward R, Zemlak TS, Innes BH, Last PR, Hebert PDN. 2005. DNA barcoding Australia's fish species. Philosophical Transactions of the Royal Society B: Biological Sciences 360: 1847-1857. 